\title{
Analysis on the Problems in the Process of Implementing Architectural Programming
}

\author{
Yunfeng Zhong \\ School of Civil Engineering and Architecture \\ Shaanxi University of Science and Technology \\ Hanzhong, Shaanxi, China 723000
}

\begin{abstract}
The architectural programming has developed quite mature in the US, Europe and Japan, while in our country it has just started. Firstly, this paper corrects the misunderstanding of architectural programming from the understanding, further points out the relationship between programming and architectural design, and the importance of programming, finally puts forward the measures that shall be taken currently in the face of the architectural programming, so as to guide the construction and architectural design of our country to develop in a more healthy and mature direction.
\end{abstract}

Keywords-architectural programming; architectural design; architect; creativity

\section{THE AWARENESS RECTIFICATION OF ARCHITECTURAL PROGRAMMING}

The architectural programming is highly valued in the architectural engineering field of Europe, the US, Japan and other economically developed countries and regions, the theories and methods of architectural programming have been quite mature, which has become a relatively independent link in the architectural activities. The domestic research and practice about architectural programming is relatively in the initial stage. The vast majority of the architects is familiar with the concept and the content, but rather vague in the cognition and understanding, and even misunderstanding its meaning. I think at present the misunderstanding of architectural programming cognition in our country can be mainly summed up as follows:

- the simplification of cognition. Architectural programming is considered as a design task book, the architectural programming is equivalent to setting the task book and giving some restriction conditions;

- the complexity of cognition. Architectural programming is equivalent to the early stage of the architectural design and contains the concept of early stage and architectural forms, as well as techniques and economy, etc., which can be easily mixed with the early architectural design;

- it is equivalent to the project pre planning and feasibility study. The core problems of domestic feasibility study currently are the risks and benefits of the investment behavior, to solve the necessity, technical possibility and reliability investment of project construction;

- the consciousness of the general citizen class is equivalent to today's hottest and most eye-catching real estate related planning, such as "real estate construction project planning", "commercial real estate project planning" or "extensive estate planning" and other consulting and management service industry.

I personally think that the above views all have cognitional misunderstandings, which are very far from the architectural programming we are to talk about. So what is the concept of architectural programming? What kind of practical problems does it solve? What is the relationship between it and the architectural design? It is to be discussed in the following article.

\section{THE RELATIONSHIP BETWEEN ARCHITECTURAL PROGRAMMING AND ARCHITECTURAL DESIGN}

Because the theoretical research and practice in China currently is mostly not practical to the understanding of the concept and method of real "architectural programming", it is basically in the phase of exploration, citation and trial. Hereby firstly explain the definition of architectural programming by American. In fact, their activities of architectural programming do not need too many definitions and explanations, almost all of the architects and the owners very understand the meaning of architectural programming which is the tool and means to communicate the demands of the ultimate users of architectures to the architects, as the guidelines and instructions for architects to develop design programs. The program design is to try to use effective form to solve the problems and status raised in the program. Architectural programming is the first stage of the architectural design process which shall determine the related value system of the owners, users, architects and the society, clarify important design objectives and disclose all kinds of status information related to the design, also explain the equipment. Then, the architectural programming is compiled into a document, which reflects the values, objectives and needs identified. In fact, programming is to find out what the problem is, architectural programming is the process of "looking for the problem", while the architectural design is the answer to these specific questions. 
Then my personal understanding is that the architectural design is considered as the exploration and definition of the essence of the design issues. In the planning program, consider the space, climate, human factors and the construction functions, listen to and understand the owners' ideas and expectations, develop guidelines for the relationship between space and the activities, under the budget of the owners find space conception suitable for development intensity and so on. Finally, through the analysis of information make a summary statement to the problems that the design is to solve. The emphasis here is that architectural programming is not a substitute for an architect's work, and it's not too early to think about what projects should look like or what building materials should be. It should describe the requirements of the design criteria, and leave the space for the designers to create the form that meets the design criteria. Architectural programming will provide the most reasonable navigation of architectural program and form to the architectural designers. Architectural programming has a guiding role in architectural design, while architectural design practice can test the effect of programming; therefore they are an interactive relationship "Fig. 1".

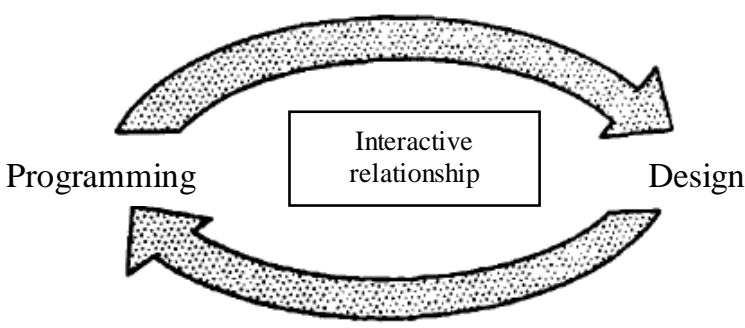

Fig. 1. Interactive relationship between Programming and Design

\section{THE IMPORTANCE OF ARCHITECTURAL PROGRAMMING}

Architectural programming is the indispensable intermediate link between urban planning and architectural design, which plays a role of connecting link between the preceding and the following, to upward infiltrate in the macroscopic overall planning and project approval link, to downward penetrate to the architectural design link, so as to ensure the science and logic of architectural design. Architectural programming is a result of "win-win" for architects, developers and owners: on one hand, the introduction of architectural programming can make the developers' investment objectives clearer, make the products' success chances greater, make the development costs effectively controlled, thus ensure the return on investment of the project; on the other hand, architectural programming brings clear design requirements to architects, so as to avoid spending a lot of energy and avoid detours due to significant modifications in design. For the owners and the society, they have been satisfied with the ideal products. Regarding architectural programming for different design projects, the problems to research and study are also different. For example, for the architectural programming of community, it may focus on the determination of community theme, the research of house type scale, the full use of land and the promotion of space value, the control of construction costs and the effective utilization of construction funds, technical and economic indicators etc.. For commercial buildings, they may do more research and analysis of market environment. In view of the appearance and economic considerations, the programming contents may be involved in architectural form, space image, the column selection, space utilization and distribution, standard layer layout etc., also according to the characteristics of commercial buildings, consider the market adaptation and contingency planning. Thus, in order to efficiently and smoothly carry out the architectural design, the architectural programming is essential.

\section{HOW TO FACE THE DOMESTIC ARCHITECTURAL PROGRAMMING}

The pre programming of domestic construction projects focuses on the project management and control while the specific programs lack real operation, or to produce the market effect as the goal, lacks the detailed and deep architectural programming analysis, leading to that the project planning results are often very difficult to translate for the physical model. Finally it can only become the beautiful text description and lengthy quotes, while the architectural programming of the US is to define the construction problem as the goal, to provide navigation for the designers to create the most reasonable program and form. Therefore, we put forward the following measures in the face of our domestic architectural environment and architectural programming.

\section{A. Pay Attention to Strengthening the Theoretical Construction of Architectural Programming}

Since the architectural programming started late in China, there are a few relevant theory books, mainly as Architectural Programming and Prophase Management written by Rober G Hershberger from the United States, Architectural Programming written by British Frank Salisbury, the relevant papers domestically, almost no books, therefore it is necessary to strengthen local theory construction of architectural programming.

\section{B. Strengthen the Government Monitoring System, the Implementation of the Architectural Programming System for Major Projects}

In order to reduce the huge market risk of construction to the owners and the community, implement the application of architectural programming. China should urge the developers, authorities, enterprises and institutions to achieve architectural programming system for major projects just like the promotion of the construction supervision system. Through the national intervention, eliminate unreasonable design projects, but also reduce the burden on society.

\section{Strengthen the Training of Architects, Open Architectural Programming Courses in the Architecture Colleges.}

There are not many universities in China opening "architectural programming" course, while the teachers to teach architectural programming are less, therefore it needs to strengthen the construction of this area. The knowledge of architects originally trained is too narrow; the lack of 
architectural programming makes them unable to put forward effective proposals. Now, the smooth promotion of architectural programming, training the qualified programming personnel is a priority. To train the qualified architectural programming personnel, to provide satisfactory architectural programming services, to build industry credibility, to obtain Party A's trust and market recognition, is the key whether the architectural programming can be implemented smoothly, which is also the key to carry out architectural programming education in universities.

\section{CONCLUSION}

Although architectural programming started late in China, it undoubtedly increased our control of the architectural design. The architectural programming can effectively guide the process of architectural design, provide an objective and real basis for architectural design, therefore, the generated architectural creativity is also true and credible, which can withstand the test of the community. I believe that in the near future with the wide use of architectural programming in architectural practice, it will further exert profound influence on the whole process of design, construction and utilization, and have a subtle effect on the architects. Challenge the architects' traditional thinking to lead us to a wider creation space, use more advanced and scientific thinking methods and technical means to discover and create richer architectural features, so as to make the architecture industry compose the tomorrow of human wisdom in the theory and practice.

\section{REFERENCES}

[1] Zhuang Weimin. Architectural Programming Guide [M]. Beijing: China Water\&Power Press,

[2] Cao Lianggong. Architectural Programming Review and Case [J]. Huazhong Architecture,

[3] Zhuang Weimin. Li Daozeng. Architectural Programming TheoryDiscussion on Design Methodology [J]. Journal of Architecture. 